\title{
EVALUATION OF MAIZE HYBRIDS TOLERANT TO PHAEOSPHAERIA LEAF SPOT, GRAY LEAF SPOT AND COMMON RUST AND YIELD
}

\author{
RENATO BARBOSA CAMARGOS ${ }^{1}$, JOÃO CANDIDO DE SOUZA ${ }^{1}$, EDUARDO ALVES ${ }^{1}$, \\ CARLOS EDUARDO CAIXETA DE CASTRO ${ }^{1}$, PAULO EDUARDO RODRIGUES PRADO ${ }^{1}$ \\ and RAFAEL PARREIRA DINIZ ${ }^{1}$
}

IUniversidade Federal de Lavras, renato.ufla@hotmail.com; cansouza@dbi.ufla.br; ealves@dfp.ufla.br; carloscaixetaagro@hotmail.com; prado017@yahoo.com.br; rafadiniz_rpd@yahoo.com.br;

Revista Brasileira de Milho e Sorgo, v.16, n.1, p. 72-81, 2017

\begin{abstract}
The objectives of this study were to identify maize hybrids which have high grain yield and resistance to Phaeosphaeria leaf spot, gray leaf spot and common rust, as well as to estimate the most efficient period for measuring the reaction of the hybrids to the pathogens. Two experiments were set up in Lavras, MG, Brazil, assessing 30 hybrids in the season of 2011/2012. The experimental design was a 6 x 5 lattice arrangement with three replications. Grain yield was evaluated and five assessments of disease severity were performed at ten-day intervals as of 60 days after maize emergence. After that, the area under the disease progress curve (AUDPC) and the Spearman correlations between the diseases and the various assessment periods for each disease were estimated. It was found that the hybrids GNZ9626 PRO and GNZ9501 PRO have high grain yield and a satisfactory level of resistance to Phaeosphaeria leaf spot, gray leaf and common rust, and that assessment of the level of resistance to these diseases should be performed in the period from 80 to 100 days after plant emergence, which provides results similar to AUDPC.
\end{abstract}

Keywords: Zea mays L., Leaf diseases, Genetic resistance.

\section{AVALIAÇÃO DE HÍBRIDOS DE MILHO À MANCHA BRANCA, CERCOSPORIOSE E FERRUGEM COMUM E À PRODUTIVIDADE}

RESUMO - Os objetivos deste trabalho foram identificar híbridos de milho que apresentem alta produtividade de grãos e resistência à mancha-branca, cercosporiose e ferrugem comum, bem como estimar a época de avaliação mais eficiente para mensurar a reação dos híbridos aos patógenos causadores dessas doenças. Para isso, foram instalados dois experimentos no município de Lavras, MG e avaliados 30 híbridos no ano agrícola de 2011/2012. O delineamento experimental utilizado foi o látice 6 x 5 com três repetições. Foi avaliada a produtividade de grãos e realizadas cinco avaliações da severidade dessas enfermidades, em intervalos de 10 dias, a partir de 60 dias da emergência das plantas. Posteriormente, estimou-se a área abaixo da curva de progresso das doenças (AACPD) e a correlação de Sperman entre as mesmas com as diversas épocas de avaliação de cada doença. Constatou-se que os híbridos GNZ9501 PRO e GNZ9626 PRO apresentam alta produtividade de grãos e satisfatório nível de resistência à mancha-branca, cercosporiose e ferrugem comum e que para a avaliação do nível de resistência a essas enfermidades deve-se optar pela avaliação no período que compreende 80 a 100 dias após a emergência das plantas, o qual fornece resultados semelhantes à AACPD.

Palavras-chave: Zea mays L., Doenças foliares, Resistência genética. 
The incidence and severity of leaf diseases has significantly increased over the past years in the maize crop in Brazil and this represents an impediment to exploiting the maximum genetic potential for grain yield in this species (Brito et al., 2012).

In this context, growing hybrids with low levels of disease resistance, inadequate management of irrigation, crop succession with the growing of maize in the second crop (off season), adoption of the no-tillage system associated with absence of crop rotation are factors which have favored the multiplication and preservation of the inoculum of pathogens, strengthening the economic losses coming from this biotic stress (Cota et al., 2013).

Maize is subject to the occurrence of dozens of diseases, many of which may cause quite significant losses in this cereal crop (Pozar et al., 2009). Among them, Phaeosphaeria leaf spot (Phaeosphaeria maydis), gray leaf spot (Cercospora zeae-maydis, $C$. zeina, C. sorghi var maydis), and common rust (Puccinia sorghi) are considered among the main diseases of this crop since they have assumed epidemic proportions in various regions of Brazil, causing leaves to dry up prematurely in susceptible hybrids, with consequent reduction of 30 to $60 \%$ in grain yield (Paccola Meirelles et al., 2001; Brito et al., 2007; Brandão et al., 2003).

For the purpose of avoiding or minimizing the damage caused by diseases in the maize crop, the use of resistant hybrids is the most efficient, rational and economical method (Brito et al., 2011). Thus, an important strategy adopted in breeding programs to control diseases of this cereal crop in a sustainable way is the concomitant evaluation of grain yield and the reaction of genotypes in the face of the main diseases of the species.

The area under the disease progress curve (AUDPC) is the most used method for discrimination of disease resistant hybrids because it allows quantifying the action of the pathogens by estimating the progress of the diseases throughout the maize cycle (Campbell \& Madden, 1990). Nevertheless, to use the AUDPC, at least three evaluations during the crop cycle are necessary (Campbell \& Madden, 1990), which is not always viable in a breeding program because generally experiments are conducted with hundreds or even thousands of genotypes in each crop season, which leads the breeder to decide to evaluate the hybrids in a single season, seeking to save time and financial resources (Lopes et al., 2011).

In light of the above, the objectives of this study were to identify maize hybrids that have high grain yield and a satisfactory level of resistance to Phaeosphaeria leaf spot, gray leaf spot and common rust, as well as to estimate the most efficient period for measuring the reaction of the hybrids to these diseases.

\section{Material and Methods}

The experiments were developed in the 2011/2012 agricultural crop season in two locations in the county of Lavras, MG, in which the no-tillage planting system was adopted with successive plantings of corn following corn. The first planting was carried out on November 17 in the experimental area of the Departamento de Biologia da Universidade Federal de Lavras (DBI/UFLA), located at $915 \mathrm{~m}$ altitude, $21^{\circ} 13^{\prime} 32^{\prime \prime} \mathrm{S}$ and $44^{\circ} 58^{\prime} 55^{\prime} \mathrm{W}$. The second planting was 30 days later on the private property Xavier, located at $865 \mathrm{~m}$ altitude, $21^{\circ} 13^{\prime} 48^{\prime \prime} \mathrm{S}$ and $45^{\circ} 04^{\prime} 54^{\prime \prime} \mathrm{W}$. The weather conditions are presented in the table 1.

Thirty maize hybrids were evaluated, 15 commercial hybrids and 15 in the final phase of evaluation of the DBI/UFLA breeding program (Table 2). 
Table 1. Data of maximum temperature (maximum T), minimum temperature (minimum $\mathrm{T}$ ), average temperature (average $\mathrm{T}$ ), precipitation $(\mathrm{P})$ and relative humidity $(\mathrm{RH})$, obtained from weather station located at the UFLA, contemplating the period of severity evaluation for the diseases resistance to Phaeospharia leaf spot, gray leaf spot and common rust.

\begin{tabular}{cccccc}
\hline Month & Maximum $\mathrm{T}\left({ }^{0} \mathrm{C}\right)$ & Minimum $\mathrm{T}\left({ }^{0} \mathrm{C}\right)$ & Average $\mathrm{T}\left({ }^{\circ} \mathrm{C}\right)$ & $\mathrm{P}(\mathrm{mm})$ & $\mathrm{RH}(\%)$ \\
\hline January & 27.28 & 18.02 & 21.69 & 529.20 & 75.57 \\
February & 29.27 & 18.29 & 23.15 & 80.40 & 70.24 \\
March & 28.64 & 17.74 & 22.25 & 133.10 & 73.28 \\
April & 27.57 & 17.12 & 21.51 & 38.80 & 76.15 \\
\hline Average & 28.19 & 17.79 & 22.15 & 195.38 & 73.81 \\
\hline
\end{tabular}

Table 2. Description of the maize hybrids used in regard to genetic base and level of resistance to Phaeospharia leaf spot (PS), gray leaf spot (GS) and common rust (CR), according to the information from the seed production companies.

\begin{tabular}{|c|c|c|c|c|c|}
\hline Hybrids & Genetic Base $^{(1)}$ & $\mathrm{PS}^{(2)}$ & $\mathrm{GS}^{(2)}$ & $\mathrm{CR}^{(2)}$ & Company \\
\hline Maximus Viptera & Single hybrid & MR & MR & MR & Syngenta \\
\hline GNZ9501 PRO & Single hybrid & $\mathrm{R}$ & $\mathrm{R}$ & $\mathrm{R}$ & Geneze \\
\hline GNZ9506 PRO & Single hybrid & $\mathrm{R}$ & MR & MR & Geneze \\
\hline GNZ9505 PRO & Single hybrid & MS & MS & MR & Geneze \\
\hline GNZ9626 PRO & Single hybrid & $\mathrm{R}$ & MR & $\mathrm{R}$ & Geneze \\
\hline GNZ9688 PRO & Single hybrid & $\mathrm{R}$ & $\mathrm{R}$ & $\mathrm{R}$ & Geneze \\
\hline DKB 390 & Single hybrid & $\mathrm{R}$ & MS & MS & Dekalb \\
\hline AG4051 & Three way hybrid & $\mathrm{R}$ & $\mathrm{R}$ & $\mathrm{S}$ & Agroceres \\
\hline P30F90 & Single hybrid & MS & $\mathrm{S}$ & MR & Pioneer \\
\hline P30F80 H & Single hybrid & MS & $\mathrm{S}$ & MR & Pioneer \\
\hline P30F87 & Three way hybrid & MR & MR & MR & Pioneer \\
\hline P32R22 H & Single hybrid & $\mathrm{S}$ & $\mathrm{S}$ & MS & Pioneer \\
\hline 30P70 H & Single hybrid & $\mathrm{S}$ & MR & $\mathrm{S}$ & Pioneer \\
\hline BM3061 & Three way hybrid & MS & MR & MR & Biomatrix \\
\hline BM207 & Double hybrid & MR & MR & MS & Biomatrix \\
\hline BIO 001 & Double hybrid & SI & SI & SI & UFLA \\
\hline BIO 002 & Three way hybrid & SI & SI & SI & UFLA \\
\hline BIO 003 & Double hybrid & SI & SI & SI & UFLA \\
\hline BIO 004 & Double hybrid & SI & SI & SI & UFLA \\
\hline BIO 005 & Intervarietal hybrid. & SI & SI & SI & UFLA \\
\hline BIO 006 & Three way hybrid & SI & SI & SI & UFLA \\
\hline BIO 007 & Three way hybrid & SI & SI & SI & UFLA \\
\hline BIO 008 & Single hybrid & SI & SI & SI & UFLA \\
\hline BIO 009 & Three way hybrid & SI & SI & SI & UFLA \\
\hline BIO 010 & Three way hybrid & SI & SI & SI & UFLA \\
\hline BIO 011 & Three way hybrid & SI & SI & SI & UFLA \\
\hline BIO 012 & Double hybrid & SI & SI & SI & UFLA \\
\hline BIO 013 & Three way hybrid & SI & SI & SI & UFLA \\
\hline BIO 014 & Double hybrid & SI & SI & SI & UFLA \\
\hline BIO 015 & Three way hybrid & SI & SI & SI & UFLA \\
\hline
\end{tabular}

${ }^{1} \mathrm{HS}=$ single hybrid; $\mathrm{HD}=$ double hybrid; $\mathrm{HT}=$ three way hybrid; $\mathrm{HI}=$ intervarietal hybrid. ${ }^{2}$ Reaction to diseases, with: $\mathrm{S}=$ susceptible, $\mathrm{MS}=$ moderately susceptible, $\mathrm{MR}=$ moderately resistant, $\mathrm{R}=$ resistant and $\mathrm{SI}=$ without information. 
The experimental design was a $6 \times 5$ triple lattice arrangement, with plots consisting of four three-meter rows spaced $0.60 \mathrm{~m}$ between rows and $0.25 \mathrm{~m}$ between plants, with a stand of approximately 66,666 plants ha-1 ${ }^{-1}$ However, only the two central rows were considered as useful for data collection.

At sowing of both experiments, $350 \mathrm{~kg} \mathrm{ha}^{-1}$ of the formula 08-28-16 $\left(\mathrm{N}, \mathrm{P}_{2} \mathrm{O}_{5}, \mathrm{~K}_{2} \mathrm{O}\right)$ was used. In top dressing fertilization, $200 \mathrm{~kg} \mathrm{ha}^{-1}$ of ammonium sulfate in the V3 phenological stage was applied and $200 \mathrm{~kg} \mathrm{ha}^{-1}$ of urea in the V6 stage. The other crop managements were performed according to the technical recommendations for the maize crop.

The experiments were conducted under conditions of natural incidence of pathogens, however for the purpose of increasing the inoculum potential in the experimental areas, the hybrid P30F53 (moderately susceptible to the three diseases evaluated) was sown at the edge and in one-meter length strips at the ends of each repetition block.

For the evaluation of the resistance level of maize hybrids, severity data (scores) of the diseases were used considering the entire useful area of the plot, obtained with the aid of the diagrammatic scale proposed by Agroceres (1996). Five evaluations were carried out, at ten-day intervals, as of 60 days after plant emergence, contemplating since the silking till dent reproductive stages. In both experiments, grain yield was evaluated, obtained in $\mathrm{kg} \mathrm{plot}^{-1}$, converted to $\mathrm{kg} \mathrm{ha}^{-1}$ and adjusted to moisture of $13 \%$.

The disease severity scores obtained in the five evaluations were used to estimate the progress of Phaeosphaeria leaf spot, gray leaf spot and common rust in the maizecrop. For this purpose, the AUDPC was calculated, as proposed by Campbell \& Madden(1990).

The data regarding AUDPC, grain yield and disease evaluation periods were subjected to individual and joint analysis of variance (Ramalho et al., 2012), using the software SAS (Sas Institute Inc, 2000). After that, the selective accuracy was estimated according to Resende (2002). The mean values of the hybrids in reference to grain yield and AUDPC were grouped by the Scott \& Knott (1974) test, using the software Genes (Cruz, 2001). The Spearman classification correlation (Stell \& Torrie, 1980) was estimated between each evaluation period of the severity of Phaeosphaeria leaf spot, gray leaf spot and common rust with the respective AUDPC by means of the software SAS (Sas Institute Inc, 2000).

\section{Results and Discussion}

Significance was found for the source of hybrids variation and environments in the joint analysis of variance for grain yield (data not presented). This indicates that at least one of the hybrids showed different performance from the others in regard to grain yield and that the soil and climate conditions of the environments differed among themselves. The hybrids $\mathrm{x}$ environments interaction source of variation was not significant, showing that the behavior of the hybrids was consistent in both environments, which facilitates the indication of the best hybrids for growing in the region.

Experimental precision for the grain yield trait was $89.74 \%$, considering the mean value of the two environments, evaluated by the accuracy, which is considered as good precision by Resende \& Duarte (2007). Mean yield was $9,562 \mathrm{~kg} \mathrm{ha}^{-1}$, which reflects the large genetic potential of the hybrids used and the high technological level adopted in the management of the experimental areas.

By means of joint analysis of variance for the AUDPC data of Phaeosphaeria leaf spot, gray leaf 
spot and common rust (data not presented), significant differences were observed for the hybrids source of variation in the three diseases evaluated. This showed that there was significant difference among the 30 hybrids measured in regard to the reaction to three pathogens.

The environment source of variation was significant for the three diseases evaluated (data not presented). Considering that the climate conditions affect the progress of these diseases, the interval of 30 days between settings up the two experiments may have contributed to intensify the differences between the environments. Planting of experiments at different times is common in agricultural experiments when diseases are evaluated under conditions of natural incidence of the pathogens (Brito et al., 2007; Julliati \& Souza, 2005; Lopes et al., 2011) in order to compare the performance of the hybrids in different environments, allowing to verify the stability of these and to draw conclusions with more consistency and reliability.

The hybrids $\mathrm{x}$ environments interaction source of variation considering the three diseases evaluated (data not shown) was not significant; it means that the behavior of the hybrids was consistent in the environments evaluated. These results corroborate the fact of resistance to Phaeosphaeria leaf spot and to gray leaf spot being of the horizontal type (Bubeck et al., 1993; Lopes et al., 2007) in which the pathogenhost interaction is less specific. In addition, there were probably pathogen populations genetically similar among themselves in the environments evaluated. In the case of resistance to common rust in maize, it may be of the horizontal or vertical type (Wisser et al., 2006). Thus, it is expected that expression of resistance was of the horizontal type, justified by the same reasons presented for Phaeosphaeria leaf spot and for gray leaf spot, or what is called as the Parlevliet effect may have occurred, in which there is a false appearance of resistance of the horizontal type, observed when the populations of host and pathogen are heterogeneous (Sidhu, 1984).

In the average of the two environments, high severity of the diseases was observed, such as indicated by the mean values of AUDPC of Phaeosphaeria leaf spot (144.00), gray leaf spot (121.14) and common rust (135.11), which allowed discrimination of the hybrids in regard to their resistance (Table 3). The values of accuracy obtained in evaluation of Phaeosphaeria leaf spot, gray leaf spot and common rust were $98.54 \%, 97.75 \%$ and $94.89 \%$, respectively, showing that the measuring of these characters presented high precision (Resende \& Duarte, 2007).

In the context of plant health assessment, generally, the occurrence of pathogens which cause leaf diseases in maize is not uniform in the experimental areas, and this reduces experimental precision (Santos et al., 2002), as may be verified in diverse studies conducted for this purpose (Brito et al., 2011; Vieira et al., 2009). The higher values of the experimental precision observed in this study may arise from the use of a border and sowing of the source of inoculum at the ends of each repetition, measures taken to contribute so that the diseases occurred with greater severity and the inocula of the pathogens were more uniformly distributed in the experiments.

In agreement with joint analysis of variation, the grouping test for AUDPC of Phaeosphaeria leaf spot, gray leaf spot and common rust exhibited distinct groups (Table 3). A great variability was observed within the hybrids evaluated in regard to reaction to the three diseases, which indicates that there is a source of genetic resistance for control of these diseases in maize, information which is of 
great relevance for directing future breeding studies.

Besides that, disease resistance levels obtained for the commercial hybrids in this study corroborate that divulged by seed companies and presented in table 2 .
The hybrids GNZ9626 PRO and GNZ9501 PRO stood out from the rest through exhibiting high grain yield and a satisfactory level of resistance to the three diseases evaluated (Table 3). They are recommended

Table 3. Grain yield values $\left(\mathrm{kg} \mathrm{ha}^{-1}\right)$ and of area under the disease progress curve (AUDPC) obtained as evaluations of severity of maize white spot (WS), gray leaf spot (GS) and common rust (CR) of 30 maize hybrids evaluated in two environments in the municipality of Lavras, MG, Brazil.

\begin{tabular}{|c|c|c|c|c|}
\hline \multirow{2}{*}{ Hybrids } & $\mathrm{WS}^{(1)}$ & $\mathrm{GS}^{(1)}$ & $\mathrm{CR}^{(1)}$ & Yield $^{(2)}$ \\
\hline & \multicolumn{3}{|c|}{ (AUDPC) } & $\left(\mathrm{kg} \mathrm{ha}^{-1)}\right.$ \\
\hline$\overline{\text { GNZ9626 PRO }}$ & $77.92 \mathrm{a}$ & $62.14 \mathrm{a}$ & $125.15 \mathrm{c}$ & $13,388 \mathrm{~A}$ \\
\hline GNZ9501 PRO & $65.82 \mathrm{a}$ & $52.19 \mathrm{a}$ & $61.74 \mathrm{a}$ & $13,003 \mathrm{~A}$ \\
\hline BM207 & $123.43 \mathrm{~b}$ & $102.10 \mathrm{~b}$ & $144.71 \mathrm{~d}$ & $11,451 \mathrm{~B}$ \\
\hline Maximus Viptera & $140.16 \mathrm{c}$ & $111.69 \mathrm{~b}$ & $111.98 \mathrm{c}$ & $11,313 \mathrm{~B}$ \\
\hline BIO 006 & $139.79 \mathrm{c}$ & $150.66 \mathrm{~d}$ & $168.39 \mathrm{~d}$ & $10,890 \mathrm{~B}$ \\
\hline BIO 007 & $180.96 \mathrm{~d}$ & $151.01 \mathrm{~d}$ & $214.66 \mathrm{e}$ & $10,875 \mathrm{~B}$ \\
\hline P30F87 & $146.24 \mathrm{c}$ & $88.24 \mathrm{~b}$ & $127.23 \mathrm{c}$ & $10,759 \mathrm{~B}$ \\
\hline GNZ9688 PRO & $68.77 \mathrm{a}$ & $47.89 \mathrm{a}$ & $46.35 \mathrm{a}$ & $10,628 \mathrm{~B}$ \\
\hline $30 \mathrm{P} 70 \mathrm{H}$ & $240.22 \mathrm{e}$ & $150.28 \mathrm{~d}$ & $188.43 \mathrm{e}$ & $10,404 \mathrm{~B}$ \\
\hline ВM3061 & $169.50 \mathrm{~d}$ & $133.43 \mathrm{c}$ & $148.53 \mathrm{~d}$ & $10,130 \mathrm{~B}$ \\
\hline BIO 009 & $156.47 \mathrm{c}$ & $157.44 \mathrm{~d}$ & $132.77 \mathrm{c}$ & $10,061 \mathrm{~B}$ \\
\hline GNZ9506 PRO & $110.38 \mathrm{~b}$ & $117.65 \mathrm{c}$ & $123.87 \mathrm{c}$ & $9,883 \mathrm{~B}$ \\
\hline DKB 390 & $66.03 \mathrm{a}$ & $161.35 \mathrm{~d}$ & $172.44 \mathrm{~d}$ & $9,872 \mathrm{~B}$ \\
\hline BIO 004 & $166.69 \mathrm{~d}$ & $110.90 \mathrm{~b}$ & $140.73 \mathrm{~d}$ & $9,512 \mathrm{C}$ \\
\hline BIO 011 & $113.77 \mathrm{~b}$ & $80.11 b$ & $119.31 \mathrm{c}$ & $9,498 \mathrm{C}$ \\
\hline P32R22 H & $250.46 \mathrm{e}$ & $189.85 \mathrm{e}$ & $175.25 \mathrm{~d}$ & $9,334 \mathrm{C}$ \\
\hline GNZ9505 PRO & $192.57 \mathrm{~d}$ & $129.65 \mathrm{c}$ & $87.79 \mathrm{~b}$ & $9,274 \mathrm{C}$ \\
\hline P30F90 & $150.22 \mathrm{c}$ & $185.19 \mathrm{e}$ & $146.28 \mathrm{~d}$ & $9,186 \mathrm{C}$ \\
\hline BIO 005 & $176.43 \mathrm{~d}$ & $144.63 \mathrm{~d}$ & $154.54 \mathrm{~d}$ & $9,124 \mathrm{C}$ \\
\hline BIO 008 & $122.14 \mathrm{~b}$ & $65.42 \mathrm{a}$ & $150.96 \mathrm{~d}$ & $9,096 \mathrm{C}$ \\
\hline BIO 013 & $144.38 \mathrm{c}$ & $134.42 \mathrm{c}$ & $109.88 \mathrm{c}$ & $8,974 \mathrm{C}$ \\
\hline AG4051 & $77.01 \mathrm{a}$ & $95.12 \mathrm{~b}$ & $193.46 \mathrm{e}$ & $8,683 \mathrm{C}$ \\
\hline BIO 010 & $166.13 \mathrm{~d}$ & $135.53 \mathrm{c}$ & $111.10 \mathrm{c}$ & $8,609 \mathrm{C}$ \\
\hline P30F80 H & $181.64 \mathrm{~d}$ & $188.63 \mathrm{e}$ & $115.51 \mathrm{c}$ & $8,586 \mathrm{C}$ \\
\hline BIO 002 & $187.20 \mathrm{~d}$ & $151.03 \mathrm{~d}$ & $83.84 \mathrm{~b}$ & $8,132 \mathrm{C}$ \\
\hline BIO 001 & $202.08 \mathrm{~d}$ & $163.06 \mathrm{~d}$ & $92.76 \mathrm{~b}$ & $8,083 \mathrm{C}$ \\
\hline BIO 012 & $136.54 \mathrm{c}$ & $100.19 \mathrm{~b}$ & $148.86 \mathrm{~d}$ & $7,959 \mathrm{C}$ \\
\hline BIO 003 & $172.31 \mathrm{~d}$ & $137.81 \mathrm{c}$ & $98.33 \mathrm{c}$ & $7,907 \mathrm{C}$ \\
\hline BIO 014 & $135.29 \mathrm{c}$ & $97.19 \mathrm{~b}$ & $141.49 \mathrm{~d}$ & $7,004 \mathrm{D}$ \\
\hline BIO 015 & $59.42 \mathrm{a}$ & $39.37 \mathrm{a}$ & $217.00 \mathrm{e}$ & $5,245 \mathrm{D}$ \\
\hline Mean & 144.00 & 121.14 & 135.11 & 9,562 \\
\hline
\end{tabular}

${ }^{1}$ Mean values followed by the same lower case letters in the column belong to the same grouping by the Scott-Knott test at $5 \%$ significance. With $\mathrm{a}=$ highly resistant; $\mathrm{b}=$ resistant; $\mathrm{c}=$ moderately resistant; $\mathrm{d}=$ moderately susceptible; $\mathrm{e}=$ susceptible. ${ }^{2}$ Mean values followed by the same upper case letters in the column belong to the same grouping by the Scott-Knott test at 5\% significance. 
for growing in regions and planting seasons in which there is greater pressure from these diseases.

Among the hybrids coming from the breeding program of DBI/UFLA, BIO 006, BIO 007 and BIO 009 exhibited yield performance similar to some commercial hybrids of high technological level, but they showed low levels of resistance to the three diseases evaluated (Table 3 ). In this case, the alternatives indicated to minimize the effect of these diseases would be growing in regions and planting times in which these leaf diseases are observed with lesser severity and adopting fungicide when it is necessary. These results reinforce the need for simultaneous evaluation of grain yield and of the level of resistance to diseases for the choice and recommendation of hybrids for growing in the different regions of the country.

By means of joint analysis of variance for the severity data, involving five evaluation periods, it was observed that the hybrid source of variation was significant in all periods (Table 4). This indicates that in each period, at least one hybrid differed from the others in regard to reaction to Phaeosphaeria maydis, Cercospora spp. and Puccinia sorghi.

Table 4. Summary of joint analysis of variance for severity of maize white spot, gray leaf spot and common rust in 30 maize hybrids evaluated at 60, 70, 80, 90 and 100 days after emergence (DAE) in two environments in the municipality of Lavras, MG, Brazil.

\begin{tabular}{|c|c|c|c|c|c|c|}
\hline \multirow{3}{*}{ Source of Variation } & \multirow{3}{*}{ GL } & \multicolumn{5}{|c|}{ Mean Squares } \\
\hline & & 60 & 70 & 30 & 90 & 100 \\
\hline & & \multicolumn{5}{|c|}{ Phaeosphaeria leaf spot } \\
\hline Hybrids & 29 & $1.32 * *$ & $4.59 * *$ & $10.41 * *$ & $13.34 * *$ & $19.36 * *$ \\
\hline Environments & 1 & $32.08 * *$ & $105.80 * *$ & $39.20 * *$ & $1.08 \mathrm{NS}$ & $51.20 * *$ \\
\hline Hybrids x Environments & 29 & $0.25^{\mathrm{NS}}$ & $0.64 *$ & $1.22^{\mathrm{NS}}$ & $1.14^{* *}$ & $1.95 * *$ \\
\hline Residue & 86 & 0.17 & 0.34 & 1.11 & 0.47 & 0.48 \\
\hline Mean & & 1.74 & 2.44 & 3.67 & 4.65 & 5.55 \\
\hline \multirow{2}{*}{ Accuracy $\left(\hat{r}_{\hat{g} g}^{2}\right)$} & & 93.22 & 96.18 & 94.51 & 98.22 & 98.87 \\
\hline & & \multicolumn{5}{|c|}{ Gray leaf spot } \\
\hline Hybrids & 29 & $0.09 *$ & $1.11 * *$ & $7.53 * *$ & $12.89 * *$ & $23.82 * *$ \\
\hline Environments & 1 & $0.00^{\mathrm{NS}}$ & $6.80 * *$ & $17.42 * *$ & $4.67 *$ & $78.67 * *$ \\
\hline Hybrids x Environments & 29 & $0.04^{\mathrm{NS}}$ & $0.37^{\mathrm{NS}}$ & $0.83^{\mathrm{NS}}$ & $0.67^{\mathrm{NS}}$ & $1.21^{\mathrm{NS}}$ \\
\hline Residue & 86 & 0.05 & 0.25 & 1.24 & 0.90 & 0.84 \\
\hline Mean & & 1.06 & 1.56 & 3.02 & 4.09 & 5.80 \\
\hline \multirow[t]{2}{*}{ Accuracy $\left(\hat{r}_{\hat{g} g}^{2}\right)$} & & 62.46 & 87.87 & 91.39 & 96.44 & 98.20 \\
\hline & & \multicolumn{5}{|c|}{ Common rust } \\
\hline Hybrids & 29 & $0.45 * *$ & $3.25 * *$ & $8.42 * *$ & $10.30 * *$ & $13.76 * *$ \\
\hline Environments & 1 & $42.05 * *$ & $61.25 * *$ & $10.27 *$ & $11.75 *$ & $8.45 *$ \\
\hline Hybrids x Environments & 29 & $0.30 * *$ & $0.55^{\mathrm{NS}}$ & $2.50^{\mathrm{NS}}$ & $1.82^{\mathrm{NS}}$ & $2.11^{\mathrm{NS}}$ \\
\hline Residue & 86 & 0.13 & 0.42 & 1.62 & 1.85 & 1.59 \\
\hline Mean & & 1.58 & 1.96 & 3.66 & 4.54 & 5.10 \\
\hline $\operatorname{Accuracy}\left(\hat{r}_{\hat{g} g}^{2}\right)$ & & 83.70 & 93.18 & 89.83 & 90.56 & 94.04 \\
\hline
\end{tabular}

ns, ${ }^{*},{ }^{* *}$ non significant, significant at $5 \%$ and $1 \%$, respectively, by the $\mathrm{F}$ test. 
In the (Table 5), Spearman correlation coefficients are represented between the severity scores of Phaeosphaeria leaf spot, gray leaf spot and common rust in each period of evaluation with the respective AUDPC, in which it is perceived that all the estimated correlations were positive and significant.

Nevertheless, at 60 and 70 days after plant emergence, Spearman correlations were estimated with values of lesser magnitude (Table 5). This is attributed to the fact of these periods of evaluation exhibiting lower mean values for the severity of these diseases (Table 3), which shows that they are not the most recommended periods for phenotypic discrimination of the level of resistance to these diseases in the maize crop.

In the results of evaluations performed at 80, 90 and 100 days after emergence of the plants, greater mean values were observed for the severity of these diseases (Table 4), also accompanied by high Spearman correlation values (Table 5). These results show that the information obtained in regard to the level of resistance of the hybrids to the diseases evaluated with the use of the AUDPC are similar to those observed upon deciding for a single evaluation from 80 to 100 days after plant emergence, which may provide for greater efficiency in the selection process.

Similar results were obtained in the study conducted by Lopes et al. (2011), in which upon evaluating Phaeosphaeria leaf spot, they found that estimates at 15 and 30 days after flowering provide positive and high magnitude correlations with the AUDPC. It was shown by the present study that even performing a single evaluation throughout the maize cycle, it is possible to discriminate the genotypes in regard to the level of resistance to the three diseases.

Table 5. Spearman correlation coefficients between the scores coming from joint analysis of variance of the severity of maize white spot, gray leaf spot and common rust at 60, 70, 80, 90 and 100 days after emergence of the plants with the respective area under the disease progress curve (AUDPC) in 30 maize hybrids.

\begin{tabular}{lccc}
\hline & AUDPC maize white spot & AUDPC gray leaf spot & AUDPC common rust \\
\hline $60 \mathrm{DAE}^{(1)}$ & 0.72 & 0.44 & 0.57 \\
& $(<0.001)$ & $(0.014)$ & $(0.001)$ \\
$70 \mathrm{DAE}$ & 0.79 & 0.83 & 0.56 \\
& $(<0.001)$ & $(<0.001)$ & $(0.001)$ \\
$80 \mathrm{DAE}$ & 0.97 & 0.97 & 0.94 \\
& $(<0.001)$ & $(<0.001)$ & $(<0.001)$ \\
$90 \mathrm{DAE}$ & 0.96 & 0.97 & 0.96 \\
& $(<0.001)$ & $(<0.001)$ & $(<0.001)$ \\
$100 \mathrm{DAE}$ & 0.93 & 0.94 & 0.95 \\
& $(<0.001)$ & $(<0.001)$ & $(<0.001)$ \\
\hline
\end{tabular}

${ }^{1} \mathrm{DAE}$ - days after emergence; in parenthesis is the probability of significance by the test. 


\section{Conclusions}

The hybrids GNZ9501 PRO, GNZ9626 PRO, BIO 006, BIO 007 and BIO 009 showed high grain yield and a satisfactory level of resistance to Phaeosphaeria leaf spot, gray leaf spot and common rust.

For evaluation of the level of resistance to the pathogens Cercospora zeae maydis, Phaeosphaeria maydis and Puccinia sorghi, the period which includes 80 to 100 days after plant emergence, in other words, period which includes milk and dent reproductive stages should be chosen for evaluation, which provides results similar to the AUDPC.

\section{Acknowledgments}

The authors wish to thank Conselho Nacional de Desenvolvimento Científico e Tecnológico (CNPq) for the financial support.

\section{References}

AGROCERES. Guia Agroceres de sanidade. São Paulo, 1996. $72 \mathrm{p}$.

BRANDÃO, A. M.; JULIATTI, F. C.; BRITO, C. H.; GOMES, L. S.; VALE, F. X. R.; HAMAWAKI, O. T. Fungicidas e épocas de aplicação no controle da ferrugem comum (Puccinia sorghi) em diferentes híbridos de milho. Bioscience Journal, Uberlândia, v. 19, n. 1, p. 43-52, 2003.

BRITO, A. H.; PEREIRA, J. L. A. R.; PINHO, R. G. V.; BALESTRE, M. Controle químico de doenças foliares e grãos ardidos em milho (Zea mays L.). Revista Brasileira de Milho e Sorgo, Sete Lagoas, v. 11, p. 49-59, 2012. DOI: 10.18512/1980-6477/rbms.v11n1p49-59.

BRITO, A. H.; PINHO, R. G. V.; SANTOS, A. O.; SANTOS, S. Reação de híbridos de milho e comparação de métodos para avaliação da cercosporiose e mancha branca. Tropical Plant Pathology, v. 36, n. 1, p. 35-41, 2011. DOI: 10.1590/S1982-56762011000100005.

BRITO, A. H.; PINHO, R. G. V.; POZZA, E. A.; PEREIRA, J. L. A. R.; FILHO, E. M. F. Efeito da cercosporiose no rendimento de híbridos comerciais de milho. Fitopatologia Brasileira, Brasília, DF, v. 32, n. 6, p. 472-479, 2007.

DOI: $10.1590 / \mathrm{S} 0100-41582007000600004$.

BUBECK, D. M.; GOODMAN, M. M.; BEAVIS, W. D.; GRANT, D. Quantitative trait loci controlling resistance to gray leaf spot in maize. Crop Science, Madison, v. 33, n. 4, p. 838-847, 1993.

DOI: 10.2135/cropsci1993.0011183X003300040041x.

CAMPBELL, L. L.; MADDEN, L. V. Monitoring epidemics. In: CAMPBELL, C. L.; MADDEN, L. V. Introduction to plant disease epidemiology. New York: John Wiley, 1990. p. 107-128.

COTA, L. V.; COSTA, R. V. da; SABATO, E. de O.; SILVA, D. D. da. Histórico e perspectivas das doenças na cultura do milho. Sete Lagoas: Embrapa Milho e Sorgo, 2013. 7 p. (Embrapa Milho e Sorgo. Circular Técnica, 193).

CRUZ, C. D. Programa Genes: aplicativo computacional em genética e estatística. Viçosa, MG: UFV, 2001. 648 p.

GOMES, F. P. Curso de estatística experimental. 14. ed. São Paulo: Nobel, 2000

JULIATTI, F. C.; SOUZA, R. M. Efeito de épocas de plantio na severidade de doenças foliares e produtividade de híbridos de milho. Bioscience Journal, Uberlândia, v. 21, p. 103-112, 2005.

LOPES, M. T. G.; LOPES, R.; BRUNELLI, K. R.; SILVA, H. P.; MATIELLO, R. R.; CAMARGO, L. E. A. Controle genético da resistência à mancha de Phaeosphaeria em milho. Ciência Rural, Santa Maria, v. 37, n. 3, p. 605-611, 2007. DOI: 10.1590/S0103-84782007000300001.

LOPES, M. T. G.; VIEIRA, M. L. C.; LOPES, R.; BRUNELLI, K. R.; MATIELLO, R. R.; SILVA, H. P.; CAMARGO, L. E. A. Progeny evaluation for resistance to Phaeosphaeria leaf spot in tropical maize. Canadian 
Journal of Plant Pathology, Ontario, v. 33, p. 49-53, 2011.

DOI: $10.1080 / 07060661.2010 .534895$.

PACCOLA-MEIRELLES, L. D.; FERREIRA, A. S.; MEIRELLES, W. F.; MARRIEL, I. E.; CASELA, C. R. Detection of bacterium associated with a leaf spot disease of maize in Brazil. Journal of Phytopathology, Berlin, v. 149, n. 5, p. 275-279, 2001.

DOI: 10.1046/j.1439-0434.2001.00614.x.

POZAR, G.; BUTRUILLE, D.; DINIZ, H. S.; VIGLIONI, J. P. Mapping and validation of quantitative trait loci for resistance to Cercospora infection in tropical maize (Zea mays L.). Theoretical and Applied Genetics, Berlin, v. 118 , n. 3, p. 553-564, 2009.

DOI: $10.1007 / \mathrm{s} 00122-008-0920-2$.

RAMALHO, M. A. P.; FERREIRA, D. F.; OLIVEIRA, A. C. Experimentação em genética e melhoramento de plantas. 3. ed. Lavras: UFLA, 2012. 328 p.

RESENDE, M. D. V.; DUARTE, J. B. Precisão e controle de qualidade em experimentos de avaliação de cultivares. Pesquisa Agropecuária Tropical, Goiânia, v. 37, n. 3, p. 182-194, 2007.

RESENDE, M. D. V. de. Genética biométrica e estatística no melhoramento de plantas perenes. Brasília, DF: Embrapa Informação Tecnológica; Colombo: Embrapa Florestas, 2002. 975 p.
SANTOS, P. G.; JULIATTI, F. C.; BUIATTI, A. L.; HAMAWAKI, O. T. Avaliação do desempenho agronômico de híbridos de milho em Uberlândia, MG. Pesquisa Agropecuária Brasileira, Brasília, DF, v. 37, n. 5, p. 597602, 2002. DOI: 10.1590/S0100-204X2002000500004.

SAS INSTITUTE. SAS software: user's guide: version 8.2. Cary, 2000. 291 p.

SCOTT, A. J.; KNOTT, M. A cluster analysis method for grouping means in the analysis of variance. Biometrics, Raleigh, v. 30, n. 3, p. 507-512, 1974.

SIDHU, G. S. Parasitic epistasis. Phytopathology, Saint Paul, v. 74, p. 382-384, 1984.

STEEL, R. G.; TORRIE, J. K. Principles and procedures of statistics: a biometrical approach. 2nd ed. Tokyo: McGraw-Hill, 1980. 633 p.

VIEIRA, R.; TESSMANN, D. J.; SCAPIM, C. A.; HATA, F. T.; RODOVALHO, M. A.; BARRETO, R. R. Genetic resistance of new popcorn hybrids to foliar diseases. Crop Breeding and Applied Biotechnology, Londrina, v. 9, n. 2, p. 140-146, 2009.

WISSER, R. J.; BALINT-KURTI, P. J.; NELSON, R. J. The genetic architecture of disease resistance in maize: a synthesis of published studies. Phytopathology, Saint Paul, v. 96, n. 2, p. 120-129, 2006.

DOI: 10.1094/PHYTO-96-0120. 